
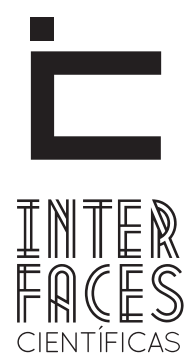

DIREITO

\title{
A PROTEÇÃO ÀS RELIGIÕES DE MATRIZ AFRICANA A PARTIR DA INSERÇÃO DE CONTEÚDOS SOBRE EDUCAÇ̃̃O PATRIMONIAL NOS CURSOS JURÍDICOS
}

\author{
Ilzver de Matos Oliveira \\ Kellen Josephine Muniz de Lima ${ }^{3}$
}

Manuella Maria Vergne Cardoso ${ }^{2}$

\section{RESUMO}

O presente artigo discutirá a importância da educação patrimonial na preservação da religiosidade de matriz africana no Brasil. Diante desse objetivo, discutimos o conceito de educação patrimonial, de comunidades tradicionais e de religiões de matriz africana. Exemplificamos a importância do tema com o debate sobre a obrigatoriedade do estudo da história e cultura afro-brasileira e africana no currículo de escolas e universidades e com a polêmica decisão judicial que recentemente definiu que candomblé e umbanda não eram religiões. Assim concluímos que diante da per- sistente intolerância aos cultos afro-brasileiros a abertura de um espaço para a educação patrimonial nos cursos jurídicos é um importante passo na construção de uma educação multicultural e para a preservação e o respeito das tradições religiosas de matriz africana no Brasil.

\section{PALAVRAS-CHAVE}

Educação Patrimonial. Educação Jurídica. Religiões de Matriz Africana. Preservação das Tradições Afro-Brasileiras. 


\section{ABSTRACT}

This article will discuss the importance of heritage education in preserving religiosity of African origin in Brazil. Given this goal, we discuss the concept of heritage education, traditional communities and religions of African origin. We exemplify the importance of the issue to the debate on the mandatory study of history and African-Brazilian and African culture in the curriculum of schools and universities and the controversial court decision recently determined that Candomblé and Umbanda religions were not. Thus we conclude that in the face of persistent

\section{RESUMEN}

Este artículo discutirá la importancia de la educación en la preservación del patrimonio religiosidad de origen africano en Brasil. Teniendo en cuenta este objetivo, se discute el concepto de la educación patrimonial, comunidades y religiones de origen africano tradicionales. Ejemplificamos la importancia de la cuestión para el debate sobre el estudio obligatorio de la historia y la cultura afro-brasileña y africana, en el plan de estudios de las escuelas y universidades, y la decisión del tribunal de controversia recientemente determinaron que Candomblé y Umbanda religiones no lo eran. Así llegamos a la conclusión que delante de la intole- intolerance African-Brazilian cults opening a space for heritage education in law courses is an important step in building a multicultural education and the preservation and respect for the religious traditions of African origin in Brazil.

\section{KEYWORDS}

Heritage Education. Legal Education. Religions of African Origin. Preservation of African-Brazilian Traditions. rancia persistente a los cultos afro-brasileños, que la apertura de un espacio para la educación del patrimonio en los cursos de derecho, es un paso importante en la construcción de una educación multicultural y la preservación y espeto a las tradiciones religiosas de origen africano en Brasil.

\section{PALABRAS CLAVE}

Equidad de la Educación; La enseñanza del Derecho; Las religiones de origen africano; La preservación de las tradiciones afro-brasileña. 


\section{INTRODUÇ̃̃̃o}

0 presente trabalho pretende analisar a importância e a relação entre a inserção de conteúdos sobre educação patrimonial nos cursos jurídicos e a preservação das tradições religiosas de origem africana no Brasil.

Partimos da ideia de que os principais espaços de formação de estudantes e profissionais do direito têm sido os tradicionais cursos jurídicos, com suas metodologias e esquemas de ensino pouco variados de um curso para o outro, quando analisamos o conjunto de instituições que no Brasil oferecem esse tipo de formação. Assim, com disciplinas criadas para abordar os conteúdos legais dos diversos ramos do direito: civil, penal, constitucional, trabalho, processual, previdenciário, tributário, entre outros bem conhecidos, resta pouco espaço para outras temáticas, sobretudo algumas importantes e recentes temáticas obrigatórias por determinação legal, como é o ensino da história e da cultura dos africanos e dos afro-brasileiros estabelecido pela Lei 10.639 de 2003 e pelo Estatuto da Igualdade Racial, Lei 12.288 de 2010.

Assim, diante desse quadro, neste artigo pretendemos inicialmente compreender os aspectos relevantes que circundam a experiência histórica das religiões afro-brasileiras com o sistema de justiça nacional. Nessa parte nos debruçamos sobre o estudo histórico e atual da amplitude da liberdade religiosa experimentada pelos cultos de origem africana, as perseguições, repressões e estratégias de luta contra a intolerância desses grupos religiosos etnicamente identificados.

Posteriormente empreenderemos análise dos conceitos fundamentais para este trabalho: educação patrimonial e comunidades tradicionais de matriz africana. E, por fim, adentrarmos no debate educacional e jurídico sobre a preservação e o respeito às tradições religiosas afro-brasileiras.

\section{PERSEGUIÇÃO ÀS RELIGIÕES DE ORIGEM AFRICANA NO BRASIL}

Em Ramos (1940), a ideia de culto fetichista, baseado em elementos míticos, envolto em segredos e mistérios, acompanha desde sua origem as religiões afro-brasileiras, e é mesmo apontada como a sua maior marca. Mandarino (2007, p. 97) destaca que a crença na magia, representada pelas religiões afro-brasileiras, e em sua capacidade de produzir malefícios por meios ocultos e sobrenaturais pode ser encontrada no Brasil desde os tempos da Colônia. Para a autora, a crença popular no Brasil, ainda hoje, atribui a determinadas pessoas o poder de causar o mal, doenças ou até mesmo a morte a outras, e isto, da mesma forma que trouxe fama para os sacerdotes e ampliou o número de adeptos nos cultos afro-brasileiros, serviu, também, como motivação para a atuação repressora de juízes, promotores, advogados e policiais a tais cultos.

O Estado, desta forma, irá se fazer presente nos assuntos acerca da magia e intervindo de forma aguda no combate a feiticeiros e macumbeiros, criando instrumentos reguladores, criando juízos especial e pessoal especializado. Mais do que isso, em alguns casos, fornecerá a própria denúncia. [...] Essa função do Estado permanece até hoje, mas, de 1890 a 1940, com as reformulações introduzidas no Código Penal, o aparato político se institucionalizou e passou a ser usado com mais intensidade como instrumento de repressão. As perseguições eram levadas a cabo, em sua maioria, através de denúncias da população que muitas vezes sentia-se incomodada pelos batuques que se arrastavam até altas horas em dias de grandes obrigações. [...] As religiões afro-brasileiras eram e continuam sendo vistas como curandeirismo, magia negra, exploração de credulidade pública e exercício ilegal da medicina, estando os seus praticantes incorrendo em crimes previstos no Código Penal. O Código Penal de 1890 incriminava não só o curandeiro, mas, também, o feiticeiro, juntamente com outras categorias, como espíritas e cartomantes. (MANDARINO, 2007, p. 97 e 100). 
A repressão policial foi uma constante na história dos terreiros ${ }^{3}$. Marina de Mello e Souza (2007, p. 115 e 116) diz que os templos afro-religiosos e os seus sacerdotes foram importantes polos de organização das comunidades negras e por conta disso até meados do século XX foram perseguidos pela polícia, tanto pelo tipo de prática ali exercida, normalmente relacionada a "forças diabólicas", quanto pelo medo que os ritos das comunidades negras despertavam, como também pelo fato de que, por serem espaços de reunião de muitos negros, apresentavam-se como ameaça potencial à ordem estabelecida, pois a religiosidade, sendo uma maneira de lidar com as adversidades da vida, proporcionava, com o auxílio dos sacerdotes, a resolução de problemas do cotidiano, a construção de comunidades negras na sociedade brasileira e das suas identidades.

Amaral (2007) diz que na segunda metade do Século XIX os sambas, batuques e divertimentos dos negros costumavam ser tolerados pelos senhores de escravos e pela sociedade com o objetivo de se evitar maiores rebeldias e desde que não perturbassem a ordem. A autora diz que os divertimentos públicos permitidos ou incentivados eram de origem católica, tais como os festejos das irmandades de negros, ou os que tinham fins pedagógicos, como as congadas, que objetivavam mostrar aos negros a conversão ao cristianismo, ou o Lambe-sujo, que tinha por objetivo ensinar a inevitável derrota dos quilombolas diante do homem branco.

No Nordeste, especialmente, por ser o espaço desta investigação, e em outras partes do país, muitas peças relacionadas com os cultos, que hoje integram o acervo de museus, tais como a Coleção Perseverança (Instituto Histórico e Geográfico de Alagoas), na cidade Maceió, objeto de estudo de Duarte $(1974,1985)$ e Lody (1985), do Museu Estácio de Lima, em Salvador, atualmente pertencentes ao acervo do Museu Afro-

3. Defendemos neste trabalho que a repressão policial e dos órgãos do sistema de justiça aos cultos afro-brasileiros ainda é um traço marcante da cultura jurídica nacional, e que se ela não é explícita como outrora, apresenta-se a partir de formas sutis e veladas de negação de direitos dos afro-religiosos. -brasileiro da Bahia, a Coleção Museu de Magia Negra do Museu da Polícia do Rio de Janeiro, estudada por Maggie (1975, 1979, 1992), e o reduzido acervo do Instituto Histórico e Geográfico de Sergipe, se constituem em doações das Secretarias de Segurança Pública e foram apreendidas durante ações policiais nos terreiros, inclusive durante cultos e processos de iniciação religiosa.

Relatos orais dos mais antigos e registros históricos destacam que os templos afro-religiosos eram obrigados a ter registro nas Secretarias de Segurança Pública, como se criminosos fossem. Além desse registro, os terreiros, para realizarem suas cerimônias, necessitavam de uma licença concedida pelo órgão policial, ou pela Prefeitura, mediante o pagamento de taxas. Isso perdurou em Sergipe, por exemplo, até o final da década de 1960, quando as Federações de Cultos Afro-Brasileiros e de Umbanda substituíram a polícia no controle sobre os terreiros (DANTAS, 1984).

A ignorância e o desconhecimento sobre a cultura negra e sua origem eram apontados como algumas das motivações principais para estas ações opressoras. Talvez por estas razões a existência de poucos registros arqueológicos deste período de perseguição, uma vez que segundo alguns autores, dependendo das motivações para a opressão aos cultos afro, políticas ou não, teremos uma determinada característica de acervo. Para Maggie (1992), o tipo de perseguição política, como ocorrida no Quebra do Xangô em Alagoas, como não é baseado na ignorância deixou para este Estado um legado de relíquias de origem africana de elevado valor artístico, histórico e econômico.

Em Sergipe o panorama político do Novo Regime de 30, é retratado por Mandarino (2007) a partir dos estudos de Costa Dantas (1983) e a autora defende haver uma relação especialmente entre o segundo mandato do Tenente Augusto Maynard (1942-1945) e a maior visibilidade das perseguições aos cultos de origem africana em Sergipe. A principal razão 
apontada é que o Tenente não permitia qualquer tipo de atitude que pudesse vir a desestabilizar seu governo (AGUIAR, 2002).

Diferentemente de outros Estados onde a década de 1940 representou o período final da repressão aos cultos africanos e o início de um momento mais tranquilo para as manifestações religiosas afro-brasileiras, em Sergipe é exatamente neste período que a opressão é ampliada. Mandarino (2007) destaca que o Decreto $n^{0} 10 / 264$ de 25 de agosto de 1942, de alguns meses após a posse do Tenente Augusto Maynard, transformou o Pelotão de Cavalaria da Polícia Militar de Sergipe em Esquadrão, com o objetivo de manter a ordem pública. Era esse Esquadrão o responsável pela perseguição aos terreiros, baseados na lei do silêncio, pela proibição do tráfego pelas ruas após as 22 horas e pelo enquadramento dos que eram assim considerados "inimigos da ordem": bêbados, prostitutas, jogadores e "macumbeiros".

O período de 1937-1945 em Sergipe será marcado pela presença de três interventores (Eronides de Carvalho, Milton Azevedo e Augusto Maynard) que irão implementar uma política ostensiva de repressão às casas de cultos que se encontravam instaladas no Estado. Se em 1934 estas para funcionarem como já foi dito, precisavam de um registro e do pagamento de uma taxa à Secretaria de Segurança Pública, neste momento irão ser perseguidas por ordem do próprio Governo, que desconhecendo o princípio de liberdade de culto promulgado pela antiga Constituição, perseguirá a todos sem trégua. [...] Passadas inicialmente as manifestações causadas pela Guerra, as mobilizações das massas tenderam a diminuir, pelo menos entre 1943-44, enquanto se desenvolvia a conscientização contra o regime autoritário. É neste momento que os candomblés de feitorio e as religiões afro-brasileiras já estabelecidas no Estado de Sergipe, irão passar por momentos de maior coerção. A necessidade de manter a ordem e o regime a qualquer custo irá recrudescer as investidas contra os adeptos. (MANDARINO, 2007, p. 115).

Assim, a ideologia autoritária e repressiva do Estado Novo repercute na relação entre os cultos de origem africana e o governo em Sergipe, de modo que chegamos até a encontrar registros que diziam que "na época não se podia acender sequer uma vela para um santo" (AGUIAR, 2002). Ressalte-se, entretanto, que o período histórico descrito foi caracteristicamente marcado por intensa repressão às reivindicações da classe trabalhadora, e esta, por via de consequência era composta em sua grande maioria por populares adeptos das religiões de matriz africana, daí a política de intolerância a tais cultos. É o que reflete Janaína Couvo Teixeira Maia (1998) ao dizer que a repressão estava presente em todo o país desde o período da escravidão e não estava voltada apenas para as religiões africanas, mas a qualquer espécie de revolta organizada pelos escravos ou negros livres.

Principal pesquisadora da cultura e religiosidade africanas em Sergipe e umas das principais do país, Beatriz Góis Dantas (1988) discute as acusações que serviram de pretexto à perseguição policial aos terreiros do Nordeste durante a Primeira República e a década de 1930. Para a autora, acusações revelam pontos de tensão na sociedade e constituem-se em atos políticos, na medida em que pretendem a eliminação de concorrentes, e no campo da religião, onde as disputas entre diferentes agências religiosas remetem às lutas propriamente políticas que se desenvolvem no âmbito da sociedade global, acusações constituem um tema sempre recorrente (DANTAS, 1988).

\footnotetext{
A oposição que historicamente se constrói entre religião e magia/feitiçaria, a primeira tida como manifestação legítima do sagrado e a segunda, como manipulação ilegítima e profana, desliza geralmente da classificação para a acusação. Através dela se desqualificam práticas, crenças e agentes religiosos. Desse modo, a religião dos vencidos, ou dos grupos estruturalmente inferiores no interior de uma sociedade, são sempre reduzidas à magia, feitiçaria e superstição. Isso aconteceu com os africanos transportados para o Brasil como escravos e persistiu no período pós-abolicionista em relação aos negros livres. Com efeito, uma das acusações mais frequentes aos terreiros de Candomblé durante a Primeira República era a prática de feitiçaria. (DANTAS, 1988).
} 
A acusação de feitiçaria, em Dantas (1988), não apenas desqualificava social e simbolicamente práticas e crenças correntes entre as camadas populares, sobretudo entre os negros, como também as jogava na ilegalidade. A acusação assumia assim um caráter coercitivo muito forte, pois se de um lado estigmatizava, de outro permitia o uso do aparato policial do Estado contra os terreiros acusados de centros de feitiçaria, prática ilegal segundo a legislação da época.

Dantas (1988) observa dois momentos históricos distintos sobre este processo de acusação contra os cultos afro-brasileiros: o primeiro, sob a égide do Código Criminal de 1830, que não incluía a perseguição aos feiticeiros, pois, segundo a autora, embora a religião dos negros fosse vista como feitiçaria, não sentiram os legisladores brasileiros necessidade de controlá-la por meio da lei enquanto vigorou a escravidão; o segundo momento, quando os negros já estão livres e, sob a vigência do Código Penal de 1890 passam a ser incriminados não só o curandeiro, mas também o feiticeiro, juntamente com outras categorias como espiritistas e cartomantes.

\begin{abstract}
Embora não faça alusão aos negros, o que iria de encontro à cidadania recém adquirida com a abolição e à igualdade assegurada pela Constituição, a repressão legal surgia como uma tentativa de garantir aos que dominavam as leis, o controle sobre os negros livres, cujos centros de culto localizados sobretudo nas cidades, constituir-se-iam em núcleos virtuais de perigo e "desordem". (DANTAS, 1988, p. 165-166).
\end{abstract}

Assim, nesse contexto legal e com a tentativa de retirar do foco do sistema penal uma parte dos cultos de origem africana, é que alguns intelectuais iniciaram estudos sobre as religiões dos negros no Brasil, tentando, em nome da ciência, delimitar os elementos que distinguiam o que era religião, relacionada à pureza africana, do que eram a magia, cultos miscigenados e sincretizados, tudo na tentativa de se alcançar a legitimação e a legalização dos terreiros "africanos mais puros". (DANTAS, 1984).
Dantas (1988) ressalta que nessa época os cultos afro-brasileiros eram vistos como uma questão que oscilava entre o crime e a anormalidade, uma vez que a interpretação da possessão pela via psiquiátrica continuava em vigor, tendo passado da mera histeria como pensado por Nina Rodrigues para com Arthur Ramos ser alçada ao status de um "fenômeno muito complexo, ligado a vários estados mórbidos" (RAMOS, 1951, p. 244).

Diante desse contexto é que ganha força como processo educativo da massa atrasada, a instalação do Serviço de Higiene Mental nas Escolas do Rio de Janeiro associada à pesquisa nos "morros", nas "macumbas" e nos "centros de feitiçaria" e sua apresentação como um "trabalho de largo alcance higiênico e educacional” (RAMOS, 1951, p. 27). Assim, abre-se espaço para um novo argumento: em nome da Psicologia, os intelectuais tentavam libertar os cultos do controle policial, para submetê-los ao controle "científico" dos centros psiquiátricos. Mas a oposição entre religião e magia, com a ideia de o Candomblé mais "puro" ser, sobretudo, religião por oposição à Macumba, Catimbó etc., voltados para a magia, não se esvai, e vai ser retomada mais tarde e bastante desenvolvida pelo sociólogo francês Roger Bastide (1971).

Essa tentativa de separação entre sacerdote e feiticeiro remete ao esforço desenvolvido pelos intelectuais no sentido de mostrar o Candomblé como verdadeira religião, por oposição à magia, particularmente à chamada preconceituosamente de "magia negra”, pois se reconhecia que "a feitiçaria era ilegal no Brasil e também que não havia lugar para ela na atmosfera amável do Candomblé da Bahia" (LANDES, 1967, p. 233). Também foi a dicotomia magia-religião que fundamentou o pensamento dos juízes nos casos analisados por Scrhitzmeyer (2004), como analisaremos posteriormente.

Também Edison Carneiro, em seus trabalhos iniciais na década de trinta, incide nessa diferenciação entre religião e magia, associando esta aos cultos 
"misturados" e aquela, aos terreiros nagôs mais africanizados. 0 charlatanismo e a exploração imperavam, segundo ele, nas sessões de caboclo, escala final do continuum construído por Artur Ramos e adotado por Edison Carneiro, tendo como ponto de partida o nagô. Diz ele:

O espiritismo, influindo sobre os candomblé afro-bantos produziu as atuais sessões de caboclo da Bahia, último degrau na escala dos candomblés, espécie de ponte para adesão completa do negro banco ao chamado baixo espiritismo. Nestas sessões de caboclo exerce-se a medicina mágica, base provável do fenômeno social do curandeirismo no Brasil. (CARNEIRO, 1981, p. 235 e 238).

O curandeirismo era prática ilegal e, assim, ao tentar criar uma legalidade para os "africanos puros", desqualifica e deslegitima os demais cultos, impingindo-lhes práticas de curandeirismo e feitiçaria. Esse ponto de vista aparece bem explicitado em outra passagem, onde o autor compara as mães-de-santo nagôs aos pais-de-santo caboclos:

Vários destes pais jamais sofrerão o processo de feitura de santo. São pais sem treino, espontâneos, distantes de orgânica tradição africana - os clandestinos do desprezo nagô [...]. São esses pais que mais tem concorrido para a desmoralização dos candomblés, entregando-se á pratica do curandeirismo e da feitiçaria - por dinheiro. Os casos de curandeirismo e de feitiçaria nos candomblés nagôs e jejes são raros, mas, quando ocorrem, se limitam a praticas mágicas inócuas, no máximo um chá de plantas medicinais ou um despacho (ebó) para Exu, na encruzilhada mais próxima. (CARNEIRO, 1967, p. 130).

Assim, vemos como a inexistência de mecanismos jurídicos que permitissem a legalização dos terreiros os levou a desenvolver, junto com seus intelectuais apoiadores, teorias antropológicas e psicológicas que de alguma forma os protegessem diante das arbitrariedades dos policiais. E quando em 1934 os terreiros foram obrigados a ter registro nos Departamentos de Polícia para funcionarem, numa tentativa de contrabalançar essa imposição do registro policial e libertar-se do estigma de clandestinidade, além do apoio dos cientistas e pesquisadores, tal como relatamos anteriormente, os terreiros passaram a ampliar suas estratégias de defesa: inicialmente, começaram a se registrar como sociedade civil; depois, passaram a criar entidades que buscavam congregar todos os terreiros.

No Recife, a legalização dos candomblés fora conseguida por meio do Serviço de Higiene Mental que funcionava como entidade que, se não substituía de todo o controle da polícia, ao menos intermediava essa relação. Na Bahia, o reconhecimento da legalidade dos terreiros ganha novo impulso em 1937 com a criação da União de Seitas Afro-Brasileiras da Bahia, entidade criada pelos intelectuais com o apoio do famoso terreiro nagô Axé-Opô-Afonjá para congregar os templos de origem africana no Estado (DANTAS, 1988).

O amplo e fluído segmento afro-brasileiro passou a ser visto como internamente diferenciado e dividido entre os que fazem religião e os que também praticam magia/feitiçaria. Nessa classificação, a origem (africana-nagô, banto ou indígena) e a ortodoxia (puros e misturados), categorias nativas adotadas pelos estudiosos, eram critérios importantes e levam os intelectuais e fixar-se na análise dos traços culturais que permitiam determinar a fidelidade dos terreiros às suas origens. Desse modo, os terreiros mais africanizados, os nagôs mais puros são recortados e alçados à posição de verdadeira religião. Através dessa aliança, os cientistas tentam conseguir para os terreiros africanos mais puros não só legitimidade, mas, também legalidade e, consequentemente, maior liberdade de atuação. (DANTAS, 1988, p. 145).

Em Sergipe essa pureza é requerida pelos seguidores dos cultos aos orixás da cidade de Laranjeiras, especialmente os da Casa Ti Herculano ${ }^{4}$,

4. Herculano foi um africano que chegou a Laranjeiras na condição de escravo, alforriou-se e como liberto conseguiu reunir um bom patrimônio material. Ganhou visibilidade na sociedade local, sobretudo como chefe religioso na tradição nagô. Ao morrer em 1907 tinha reunido um patrimônio considerável avaliado em dois contos e 66 mil réis, muito acima dos padrões dos pobres da localidade à época, nesse patrimônio se incluía a casa onde residia e onde estava sediado o terreiro nagô que ele dirigia. A Casa de Ti Herculano remonta à segunda metade do século XIX, e foi o segundo espaço em que se organizaram os cultos coletivos de matriz africana em Laranjeiras, seguindo a Casa de Ti Henrique, hoje desaparecida. A Casa foi herdada pela viúva Bernarda Barbosa e os santos de Ti Herculano passaram aos cuidados dos seus descendentes. 0 cargo de chefia 
ligados ao Terreiro de Santa Bárbara Virgem, reformado pelo Instituto do Patrimônio Histórico e Artístico Nacional (IPHAN). A Irmandade Nagô de Laranjeiras se autodenomina a única pura do Brasil, por manter as raízes africanas da mesma forma em que foram trazidas até a atualidade. Essa tradição nagô começou a se formar na cidade na metade do século XIX quando lá conviviam diversas formas religiosas, como o islamismo africanizado dos malês e o catolicismo.

Foi a partir da Casa de Ti Herculano que a religião dos nagôs se estendeu para localidades vizinhas onde havia concentração e africanos cultuadores de orixás, por isso que ele é tido como um espaço de afirmação identitária e responsável principal pela rede de solidariedade e afinidades que englobava africanos e seus descendentes em busca de um lugar na sociedade (IPHAN, 2011).

Nos anos 1930, entretanto, segundo Dantas (1988), os intelectuais passaram a não se limitar a observar, descrever e interpretar os cultos, e começaram a deles participar, às vezes como ogãs e tentam intermediar as relações com a polícia. Na conjuntura política da primeira metade da década de 1930 e sobretudo no clima de movimentação vivido no Nordeste, nesse período em que a atuação do Partido Comunista resultou em levantes que atingiu a região, alguns desses intelectuais eram vistos com desconfiança pelo Governo.

No Recife, Ulisses Pernambucano, o idealizador e organizador do Serviço de Higiene Mental, líder do grupo de estudiosos de Xangô que tentava o "controle científico" dos cultos pela via psiquiátrica, é preso em 1935 sob a acusação de comunista (CERQUEIRA, 1978). O mesmo ocorre com Edison Carneiro, estudioso dos candomblés da Bahia, que

do grupo foi transmitido a Umbelina Araújo, que, no início do século XX, passou a realizar parte dos 'festejos' em sua casa - o Terreiro de Santa Bárbara Virgem - na Rua da Cacimba. Contudo, a Casa de Ti Herculano permanece como casa matriz e espaço referencial da tradição nagô de Laranjeiras. A restauração da Casa de Ti Herculano desencadeou um processo de conhecimento sobre um personagem vinculado à religiosidade afro-descendente na cidade de Laranjeiras. aí organiza, em 1937, a União de Seitas Afro-Brasileiras (LANDES, 1967) e o Segundo Congresso Afro-brasileiro realizado em 1937.

Assim, fecha-se o ciclo das espécies de acusações impingidas às religiões afro-brasileiras: 1) a acusação de feiticeiros, relacionada ao campo da religião, domínio explorado, sobretudo pela Antropologia; 2) a acusação da possessão como estado patológico, ligada ao campo de estudo da Psiquiatria; e 3) diante da necessidade sentida pelo Estado de um controle mais efetivo da massa negra, emerge a nova acusação: de comunistas, atrelada à Política.

Nas duas primeiras espécies de acusação a ciência se julgava competente para questionar a validade da repressão policial, colocando-se como a instância capaz de fornecer critérios para isolar os sacerdotes dos feiticeiros e os anormais dos mistificadores e exploradores, e assim uma parte dos cultos afro-brasileiros, os mais "puros" colocavam-se fora do alcance da polícia, pois suas práticas, segundo o aval dos cientistas, era religião e não constituíam infrações às leis.

Entretanto, com a nova acusação de comunismo, esses "nichos", frequentados habitualmente por negros e brancos pobres e também por alguns intelectuais, que com eles estabeleceram alianças, apareciam aos Governos - autoritários e ávidos por ordem e avessos e assustados com os movimentos das camadas populares - como particular $\neg$ mente perigosos e isso, mais uma vez, passou a legitimar a repressão policial contra os terreiros brasileiros.

Mas, para complementar a explicação sobre as motivações para as perseguições aos cultos de origem africana, segundo Dantas (1988, p. 162-165) é preciso ressaltar que a década de 1930 , também, foi o período de formulação do mito da democracia racial e do que alguns autores como Fry (1977) chamam de período de "domesticação" das diferenças raciais brasileiras, afinal era preciso criar mecanismos de controle dos 
negros "que poderiam utilizar suas diferenças culturais expressas sobretudo na religião, canalizando-as para melhorar sua situação sócio-econômica e alterar relações de poder secularmente estabelecidas" (DANTAS, 1988, p. 162).

É naquela década, ainda, argumenta Dantas (1988), que as manifestações culturais subalternas, tais como o carnaval, as escolas de samba, a música popular e a umbanda, passam por um intenso processo de apropriação pelas classes dominantes hegemônicas e até mesmo de ressignificação. Danças de origem africana, por exemplo, passam a ser designadas de folguedos folclóricos e atreladas agora como elementos representativos de uma cultura nacional, não mais negra ou africana, como prega a teoria da democracia racial.

Diante do crescimento e propagação dos cultos de origem africana, passa a ter destaque no cenário nacional a atuação da polícia na repressão aos cultos afro-brasileiros. Em Sergipe, Mandarino (2007) destaca que no período de maior repressão aos cultos de origem africana, na transposição do governo entre Eronides de Carvalho e Augusto Maynard, não são encontrados registros jornalísticos sobre perseguições a cultos afro-brasileiros. Só a partir do final da década de 1940 e durante a década de 1950 é que são encontradas notícias de jornais sobre a posição da sociedade sergipana em relação a tais cultos. É este período que coincide com a democratização do país e com o início do processo organizativo dos templos afro-brasileiros em Federações.

Assim, diante do aqui exposto fica evidenciado como que as religiões de origem africana foram historicamente alvo de diferentes modelos de acusação e perseguição. Em cada Região ou Estado ela se apresenta com peculiaridades, mas, de modo geral traz a marca da atuação Estatal no controle do estranho e do supostamente perigoso para a ordem estabelecida.

\section{CASO MPF X GOOGLE LTDA. E A POLÊMICA SOBRE O QUE É E O QUE NÃO É RELIGIÃO NO BRASIL}

Os atos de repressão e desconsideração às religiões de atriz africana no Brasil não podem ser considerados apenas coisas do passado. Recentemente, por exemplo, gerou grande polêmica nacional uma decisão judicial proveniente do processo $n^{0}$ 0004747-33.2014.4.02.5101 e escrita pelo Juiz Eugenio Rosa de Araújo, Juiz Federal Titular da $17^{a}$ Vara Federal no Rio de Janeiro, resultado de uma Ação Civil Pública ajuizada pelo Ministério Público Federal em desfavor do Google Brasil Internet LTDA. com o objetivo de ver retirado do sistema Google vídeos em que membros da Igreja Universal do Reino de Deus aviltavam as religiões afro-brasileiras, seus símbolos, ritos e seus sacerdotes.

A decisão do Juiz negou o pedido de retirada dos vídeos da internet sob o fundamento que no caso concreto somente existiu uma concorrência entre os direitos fundamentais e não uma violação aos direitos de liberdade de consciência e liberdade de crença, bem como o de proteção às suas liturgias, dentre outros como o direito de liberdade opinião, de reunião e de religião.

Ainda neste contexto a decisão aduz que o candomblé e a umbanda não contêm os traços necessários de uma religião: um texto base (corão, bíblia); estrutura hierárquica; e, ainda, um deus a ser venerado.

Desse breve apanhado da decisão, surgem algumas indagações: seria certo então concluir que só é religião aquela manifestação que possui textos-base tradicionais expressos, escritos e formais? É possível a definição de religião por um membro do Poder Judiciário?

Inicialmente, observamos no caso uma ausência de interpretação extensiva do termo religião, já que 
a própria Constituição no seu artigo $5^{\circ}$, inciso $\mathrm{VI}$, garante a liberdade de crença de forma plena sem que em momento algum estabeleça restrições ou solicite um texto base para a caracterização de uma religião.

Em seguida, ressaltamos que a supracitada decisão indica que os vídeos constantes no Google não são uma ofensa às liberdades públicas e tão pouco colocam em risco a prática cultural das manifestações afro-brasileiras. Mas, fato é que a Constituição Federal dispõe de normas que ao mesmo tempo criam tanto o dever de não discriminar (discriminação negativa) como o dever de igualar (discriminação positiva). Assim quando invocamos o termo "laico", que é utilizado no preâmbulo da Constituição para informar que o Brasil não possui uma religião específica e que todas as religiões - vale dizer, independentemente de ter ou não texto-base - serão tratadas de forma igualitária, queremos dizer que todas merecem respeito e proteção do Poder Público.

0 constituinte assegurou no artigo $5^{\circ}$ a liberdade de consciência e de crença, "sendo assegurado o livre exercício dos cultos religiosos e garantida, na forma da lei, a proteção aos locais de culto e a suas liturgias" (inciso VI), logo possibilitou a manifestação livre quanto à religião escolhida, bem como impôs proteção à promoção livre da religiosidade desejada.

O ordenamento jurídico brasileiro desde a primeira Constituição republicana (1891) adota o modelo laico, ou seja, não possui uma religião especifica o que permite a prática indiscriminada de qualquer tipo de religião, crença, culto e etc. A partir do momento que o constituinte decidiu pela laicidade o Estado passou a não estabelecer, não interferir e não participar dos atos relativos à religiosidade, conforme preconiza o artigo 19, CF, que veda à União, Estados, Municípios e ao Distrito Federal estabelecer cultos religiosos ou igrejas, subvencioná-los, embaraçar-lhes o funcionamento ou manter com eles ou seus representantes relações de dependência ou aliança, ressalvada, na forma da lei, a colaboração de interesse público (inciso I), estabelecendo-se um pacto de separação entre o Estado e a Religião.

Cabe ressaltar, também, que a Constituição de forma clara em seu artigo $5^{\circ}$, inciso XVI, garante o direito à liberdade de reunião como uma forma legítima de liberdade para circulação de ideias seja ela de cunho social, religioso, político dentre outros.

Assim, a veiculação de vídeos que vilipendiam a imagem das religiões afro-brasileiras e sua manutenção pelo Poder Judiciário sob o argumento de que se trata de manifestação da liberdade de expressão, reflete a perpetuação de uma realidade cultural preconceituosa em relação às religiões de matriz africana no Brasil.

Em momento algum em nossa Constituição o constituinte autorizou a violação de direitos fundamentais. A violação à liberdade de crença não pode ser assegurada pela liberdade de expressão. Aliás, qualquer forma de violação a direito de outrem já desconstitui e deslegitima a situação como manifestação da liberdade de expressão. Quando a Constituição de 1988, aduz a liberdade de expressão em seu artigo $5^{\circ}$, IV,V,X,XIII e XIV, em momento algum é permitido a utilização do direito de opinar contra alguém ou algo de forma a diminuí-lo. 0 que se almeja é a constante busca por um instrumento de divulgação e difusão da informação de forma democrática e não discriminatória.

Com a era da informática cada vez mais se torna difícil controlar o fluxo de informações que são postadas nas redes virtuais, contudo o sistema jurídico deve buscar alternativas legais para tentar minimizar essa avalanche de noticias, vídeos, posts, scraps, dentre outros instrumentos aparentemente inofensivos, mas, severamente lesivos à honra e imagem de determinados indivíduos ou grupos, como as comunidades tradicionais de matriz africana. Essa é a parcela de contribuição que o judiciário pode dar ao processo educacional em prol da proteção e preservação do patrimônio cultural afro-brasileiro. 


\section{EDUCAÇÃO PATRIMONIAL E DO ENSINO JURIIICO NA PROTEÇÃO DAS TRADIÇ̃̃ES CULTURAIS E RELIGIOSAS AFRO-BRASILEIRAS}

Mesmo com todos os avanços identificados no âmbito da educação nos últimos anos com a emergência de leis, órgãos e regulamentações voltados a discussões como etnia, raça, gênero, sexo, diferenças, identidades, diversidades, regionalidades, entre outros temas importantes, um assunto ainda permanece pouco abordado nesse campo: a educação para a preservação do patrimônio cultural.

A educação patrimonial é interpretada por Horta (1999, p. 6) como "um processo permanente e sistemático de trabalho educacional centrado no Patrimônio Cultural como fonte primária de conhecimento e enriquecimento individual e coletivo". Nas normas educacionais brasileiras, nos poucos momentos em que há referência explícita e direta ao termo "educação patrimonial”, a exemplo do Manual Operacional de Educação Integral, onde são traçados os macrocampos do Programa Mais Educação do Governo Federal, ela é conceituada como um mecanismo de incentivo à produção artística e cultural dos estudantes, de possibilidade de reconhecimento e recriação estética de si e do mundo e de valorização do patrimônio material e imaterial.

Para o documento do Ministério da Educação, a educação patrimonial tem por fim "promover ações educativas para a identificação de referências culturais e fortalecimento dos vínculos das comunidades com seu patrimônio cultural e natural, com a perspectiva de ampliar o entendimento sobre a diversidade cultural” (MEC, 2013, p. 14-15).

De forma indireta, a Constituição Federal de 1988 inseriu o conceito de patrimônio cultural, aduzindo a proteção de bens individualmente ou em conjunto desde que portadores de referências à identidade, à nação, à memória dos diferentes grupos formadores da sociedade brasileira, e no artigo 210 que "serão fixados conteúdos mínimos para o ensino fundamental, de maneira a assegurar formação básica comum e respeito aos valores culturais e artísticos, nacionais e regionais".

Em janeiro de 2003 foi sancionada a Lei 10.639 que alterou a Lei $n^{\circ} 9.394$, de 20 de dezembro de 1996, a Lei de Diretrizes e Bases da Educação Nacional, para incluir no currículo oficial da Rede de Ensino a obrigatoriedade da temática "História e Cultura Afro-Brasileira”. Tais alterações surgiram como uma forma de implementar ações e políticas educacionais permanentes que auxiliassem na formação de uma consciência do papel do povo negro na nossa sociedade.

A lei tornou obrigatória a inclusão do estudo da História da África e dos Africanos, a luta dos negros no Brasil, a cultura negra brasileira e o negro na formação da sociedade nacional, em todos os conteúdos programáticos oriundos dos estabelecimentos de ensino fundamental e médio, oficiais e particulares, como forma de resgatar a importância dos africanos e dos afro-brasileiros na formação do Brasil. E posteriormente, por meio do Parecer do Conselho Nacional de Educação n0 03/2004, que estabelece as Diretrizes Curriculares Nacionais para a Educação das Relações Étnico-Raciais e para o Ensino de História e Cultura Afro-Brasileira e Africana estabeleceu que tais determinações servissem para todos os níveis de ensino:

Reconhecimento requer a adoção de políticas educacionais e de estratégias pedagógicas de valorização da diversidade, a fim de superar a desigualdade étnico-racial presente na educação escolar brasileira, nos diferentes níveis de ensino. (BRASIL, 2004, p. 3).

E ainda determinou:

Para tanto, os sistemas de ensino e os estabelecimentos de Educação Básica, nos níveis de Educação Infantil, Educação Fundamental, Educação Média, Educação de Jovens e Adultos, Educação Superior, precisarão providenciar: (BRASIL, 2004, p. 13). 
Assim é que nesse trabalho defendemos que não obstante a existência de medidas legislativas e políticas públicas educacionais que visam incentivar a colaboração mútua entre Estado e sociedade civil para a preservação e a salvaguarda dos patrimônios culturais imateriais, tais políticas ainda não são suficientes para transformarem o quadro de persistente desrespeito, desconsideração e de violação de direitos de algumas manifestações culturais, sobretudo em relação àquelas enquadradas fora do eixo cultural hegemônico, como são, por exemplo, as originárias do continente africano e que aqui, no continente americano, foram transformadas e atualizadas em expressões culturais afro-brasileiras e muito mais que isso, alçadas em âmbito constitucional a status especial, como o foram as denominações religiosas de matriz africana, hoje protegidas na Constituição sob o manto do princípio da liberdade de expressão religiosa.

Tais denominações religiosas, e seus seguidores, hoje elementos que compõem o conceito de comunidades tradicionais de terreiro estabelecido pela legislação nacional, historicamente eram identificadas como folclore, não como religião, justamente por provirem das camadas populares da sociedade, por congregarem entre seus adeptos estratos sociais inferiores, como negros, escravos e libertos, e por praticarem ritos e cerimônias considerados bárbaros e primitivos, entre outros aspectos muito bem abordados em importantes estudos como os da antropóloga sergipana Beatriz Góis Dantas e os de Reginaldo Prandi, entre outros estudiosos das tradições religiosas de origem africana em nosso país, que analisaremos a seguir com o objetivo de traçar um panorama conceitual e caracterizador dessas denominações religiosas que compõem o rico e diverso campo religioso brasileiro, tentando apresentar nossa contribuição para esse debate em torno da preservação das tradições religiosas afro-brasileiras por meio da educação patrimonial no ensino jurídico.

\section{CONCLUSÃO}

A discussão central relativa à necessidade de políticas educacionais que incentivem a formação de uma corrente educacional efetiva no que se refere à preservação do patrimônio cultural dos povos afro-brasileiros já é realidade no Brasil. E, como principais instrumentos oficiais desta promoção, destacamos o artigo 210 da Constituição Federal, os Parâmetros Curriculares Nacionais (PCN), a Lei no 10.639 que alterou a Lei n 9.394, de 20 de dezembro de 1996, que estabelece as diretrizes e bases da educação nacional, para incluir no currículo oficial da Rede de Ensino a obrigatoriedade da temática "História e Cultura Afro-Brasileira”, e o Parecer CNE/CP 3/4, sem esquecer o Estatuto da Igualdade Racial.

Em relação ao tratamento dado às religiões afro-brasileiras constatamos que embora possuam uma tradição milenar, no Brasil permanecem incompreendidas por muitos, exemplo recente, foi a decisão do Magistrado citada no corpo deste trabalho.

Deste modo, defendemos que é dever dos cursos jurídicos a assunção da responsabilidade em promover medidas de valorização e de difusão da cultura e da pluralidade de nossa formação étnica e religiosa, com vistas à construção de um país que possua uma educação pautada no respeito e no pluralismo cultural para buscar a concretização do ideal de justiça social, de igualdade e de democracia. 


\section{REFERÊNCIAS}

AMARAL, Sharyse Piroupo do. Escravidão, Liberdade e Resistência em Sergipe: Cotinguiba, 18601888 (Tese de doutorado). Universidade Federal da Bahia, Faculdade de Filosofia e Ciências Humanas, 2007.

BRASIL. Constituição da república federativa do Brasil, 1988. Disponível em:<http://www.planalto. gov.br/ccivil_03/constituicao/constitui\%C3\%A7ao. htm>. Acesso em: 20 mar. 2008.

BRASIL. Parecer do Conselho Nacional de Educação/ Conselho Pleno/DF n³ 3, de 2004 (Relatora Petronilha Beatriz Gonçalves e Silva).

CARNEIRO, Edison. Situação do negro no Brasil. Estudos Afro-Brasileiros. Rio de Janeiro: Ariel, 1935.

CINTRA, Raimundo. Candomblé e umbanda: o desafio brasileiro. São Paulo: Paulinas, 1985.

DANTAS, Beatriz Góis. Vovô Nagô Papai Branco; usos e abusos da África no Brasil (Dissertação de mestrado). Unicamp, Campinas, 1988.

FREIRE, Paulo. Educação e Mudança. Trad. Moacir Gadotti e Lílian Lopes Martin. 3.ed. Rio de Janeiro: Paz e Terra, 1981.
HORTA, Maria de Lourdes P., GRUNBERG, Evelina, MONTEIRO, Adriane Queiroz. Guia Básico de Educação Patrimonial. Brasília: Instituto do Patrimônio Histórico e Artístico Nacional, Museu Imperial, 1999.

MANDARINO, Ana Cristina de Souza. (Não) deu na primeira página: macumba, loucura e criminalidade. São Cristovão: UFS, 2007.

PRANDI, Reginaldo. 0 Brasil com axé: candomblé e umbanda no mercado religioso. Estudos avançados 18 (52), 2004. Disponível em:

<http://www.scielo.br/pdf/ea/v18n52/a15v1852. pdf>. Acesso em: 31 out. 2008.

RAMOS, Artur. 0 negro brasileiro, etnografia religiosa. São Paulo. Nacional, 1934.

RODRIGUES, Alfredo Sotero Alves. Comunidades de terreiro e movimentos sócio-políticos no Brasil. XI Congresso Luso-afrobrasileiro de Ciências Sociais. Salvador, 2011.

RODRIGUES, Nina. Os africanos no Brasil. São Paulo: Nacional, 1932.

SODRÉ, Muniz. 0 terreiro e a cidade: a forma social negro-brasileira. Petrópolis: Vozes, 1988.

SOUZA, Marina de Mello e. África e Brasil africano. 2.ed. São Paulo: Ática, 2007.
Recebido em: 22 de Julho 2014 Avaliado em: 1 de Agosto de 2014 Aceito em: 2 de Agosto de 2014

\begin{abstract}
1. Doutor em Direito PUCRio. Mestre em Direito - UFBA. Professor Pleno do Mestrado em Direito da Universidade Tiradentes. Vice-líder e pesquisador do Grupo de Pesquisa Políticas Públicas de Direitos Humanos - UNIT-CNPq. E-mail: ilzver@gmail.com

2. Mestranda em Direitos Humanos pela Universidade Tiradentes. Pós Graduada em Direito Público (Constitucional, Administrativo, Tributário e Fazenda Pública) - Uniderp/Lfg. Professora de Direito Civil e do Trabalho da Faculdade Fasete. Estudante do Grupo de Pesquisa Políticas Públicas de Direitos Humanos - UNIT-CNPq. E-mail: manuellavergne@hotmail.com. 3. Advogada, Membro da Comissão de Igualdade Racial da OAB-SE, Especialista em Direito Civil e Processual Civil e Graduada em Direito pela Universidade Federal de Sergipe. Estudante-pesquisadora do Grupo de Pesquisa Políticas Públicas de Direitos Humanos - UNIT-CNPq. E-mail: kellen_muniz@yahoo.com.br
\end{abstract}


